\title{
Fishery characteristics of burbot - Lota lota (L.) of Lake Ladoga (Karelian part) at the present stage
}

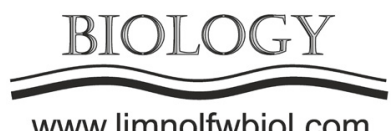

\author{
Cherepanova N.S. ${ }^{1}$, Shirokov V.A. ${ }^{1}$, Kovalenko V.N. ${ }^{2}$, Georgiev A.P. ${ }^{2 *}$ \\ ${ }^{1}$ Northern Research Institute of Fisheries in Petrozavodsk State University, emb. Varkaus 3, Petrozavodsk, 18591, Russia \\ ${ }^{2}$ Northern Water Problems Institute of the Karelian Research Centre of the Russian Academy of Sciences, Alexander Nevsky prospect \\ 50, Petrozavodsk, 185030, Russia
}

\begin{abstract}
The results of work carried out within the framework of forecast topics and economic contractual topics (NRIF PetrSU, NWPI KarRC RAS) to assess the stock and production of burbot in Lake Ladoga are presented. There were studied its main biological and structural-population indicators. The calculations of indicators of its number, biomass, the value of the fishing load at the present stage, necessary for the rational regulation of the fishery, have been carried out.
\end{abstract}

Keywords: burbot, Karelia, fishing, biology, abundance, biomass, stock status.

\section{Introduction}

The object of our research is burbot - fish, also of secondary commercial value, usually comes across as a by-catch when hunting for valuable species in fixed seines, nets and festoons; his reserves are most often underutilized. There is no processing of burbot in Karelia, its entrails are usually thrown away, although, for example, in Finland salted caviar of burbot is much more expensive than salmon. The purpose of this work is to assess the current state of burbot populations of Lake Ladoga (Karelian part).

\section{Materials and methods}

The main part of the material was collected from our own net catches, carried out for research purposes carried out within the framework of forecast topics and economic contractual topics (NRIF PetrSU, NWPI KarRC RAS). Cameral processing of ichthyological materials was performed according to generally accepted methods. The coefficients of natural mortality (M) and fishing mortality (F) were determined according to the recommended methods (Zykov, 1986; Babayan et al., 2018). The assessment of the size of the possible catch was carried out based on the norms of safe annual harvest (Malkin, 1999).

\section{Results and discussion}

Burbot Lota lota (Linnaeus, 1758) is a typical representative of the Arctic ichthyofauna in Lake Ladoga and is widespread. It is an indicator of water purity. It prefers cold and clean places with $\mathrm{r}$ sandy or silty bottom. Catches of burbot in the northern part of Lake Ladoga are relatively stable from the 1950s to the end of 1990 and fluctuate over five years in the range of 5.0-9.8 tons. For some years, the commercial catch of burbot was characterized by a very steady increase in catch values. The maximum catches were recorded in 2006-2010 - 20.8 tons and in 2011-2015 - 12.0 tons. The reason for such still low catches is predetermined by the biology of burbot (during the period of fishing activity, significant accumulations of burbot do not form and remain at great depths), the organizational side of the fishery (its minimum activity in winter is the period of the highest spawning concentrations of burbot) and low market demand from for small sizes. In addition, over the past 20 years, the state of aquatic ecosystems in the Republic of Karelia and their aquatic biological resources has been formed and develops in an environment of fluctuations in the production of various industries and agriculture and with a slight warming of the climate (Georgiev and Nazarova, 2015), which also influenced the nature of burbot catches. By the nature of its diet, burbot is a bottom predator, although it feeds on various invertebrates until the age of one year, and switches to an exclusively fish diet only at the age of 3-4 years. In Lake Ladoga with massive fish species (vendace, smelt), it usually follows their spawning or feeding accumulations. The spawning period for Ladoga burbot begins in mid-January and lasts 1.5-2.0 months. The depths at which burbot spawn varies from 3 to $30 \mathrm{~m}$. The spawning sites have clay soils and are located on the slope of the bottom depressions and near the abyssal sections. Burbot spawns near the banks and

*Corresponding author.

E-mail address: a-georgiev@mail.ru (A.P. Gergiev)

(C) Author(s) 2020. This work is distributed under the Creative Commons Attribution 4.0 License. 
Table 1. Biological indicators of burbot of Lake Ladoga (nets 40-80 mm) according to 2005-2018 data

\begin{tabular}{|c|c|c|c|c|c|c|c|c|c|c|c|}
\hline \multirow{2}{*}{ Indicators } & \multicolumn{10}{|c|}{ Age, years } \\
\cline { 2 - 10 } & $5+$ & $6+$ & $7+$ & $8+$ & $9+$ & $10+$ & $11+$ & $12+$ & $13+$ & $14+$ & $15+$ \\
Length (AD), cm & 37.4 & 41.2 & 44.8 & 48.0 & 51.3 & 54.2 & 57.0 & 59.8 & 62.5 & 65.0 & 67.4 \\
Weight, g & 575 & 738 & 906 & 1094 & 1288 & 1490 & 1710 & 1930 & 2150 & 2380 & 2625 \\
Age composition \% \\
in the catch
\end{tabular}

in river mouths. In rivers, burbot lays eggs in rather shallow areas from 0.7 to $2.0 \mathrm{~m}$. The absolute fecundity of females varied within 200-3000 thousand eggs. The linear-weight characteristic of burbot is given in Table 1.

The raw material reserves of this fish are currently underutilized by the fishery in the conditions of Lake Ladoga. The calculation of the stock size was carried out on the assumption of the constancy of the biological parameters of the population and the intensity of fishing for the forecast period. The TAC value of burbot was determined in the volume of production of surviving fish of the mature part of the population. On the basis of the performed calculations of the abundance and biomass, it was found that the production and commercial capabilities of burbot in the lake are at a good level (Table 2).

Thus, taking into account the current form of exploitation of this species, at the present stage it is possible to establish TAC in the amount of about 21 tons, or about $20 \%$ of the stock, which does not contradict the recommended rate of annual removal of burbot of 20-27\% (Malkin, 1999).

\section{Conclusions}

Based on the foregoing, it can be concluded that the stocks of burbot in the Karelian part of Lake Ladoga are in good condition. At the same time, its production potential is not fully utilized by the fishing industry. With rational management of the economy in the near future, it is possible to ensure that catches are obtained at a sufficiently high level.

\section{References}

Babayan V.K., Bobyrev A.E., Bulgakova T.I. et al. 2018. Metodicheskiye rekomendatsii po otsenke zapasov prioritetnykh vidov vodnykh biologicheskikh resursov [Methodical recommendations for the assessment of stocks of priority types of aquatic biological resources]. Moscow: VNIRO Publishing House. (in Russian)

Georgiev A.P., Nazarova L.E. 2015. Transformation of the fish part of the community in freshwater ecosystems of the Republic of Karelia under the conditions of climate variability. Ekologiya [Ecology] 44: 272-279. (in Russian)

Malkin E.M. 1999. Reproduktivnaya i chislennaya izmenchivost' promyslovykh populyatsiy ryb [Reproductive and numerical variability of commercial fish populations]. Moscow: VNIRO Publishing House. (in Russian)

Zykov L.A. 1986. Method for assessing the coefficients of natural mortality differentiated by age of fish. Izvestiya Gosudarstvennogo Nauchno-Issledovatel'skogo Instituta Ozernogo i Rechnogo Rybnogo Khozyaystva [Bulletin of the State Research Institute of Lake and River Fisheries] 243: 14-21. (in Russian)

Table 2. Abundance (N), biomass (B) and production of surviving fish (P) of burbot of Lake Ladoga (Karelian part) according to $2005-2018$ years

\begin{tabular}{|c|c|c|c|c|c|}
\hline Age, years & M, 1/year & F, 1/ year & N, thousand & B, t & P, t \\
\hline $5+$ & 0.223 & 0.040 & 41.0 & 23.5 & 6.2 \\
$6+$ & 0.193 & 0.166 & 31.6 & 23.2 & 5.2 \\
$7+$ & 0.177 & 0.285 & 22.0 & 20.1 & 3.9 \\
$8+$ & 0.172 & 0.389 & 13.9 & 15.2 & 2.6 \\
$9+$ & 0.176 & 0.308 & 7.9 & 10.2 & 1.5 \\
$10+$ & 0.188 & 0.337 & 4.9 & 7.3 & 1.0 \\
$11+$ & 0.207 & 0.211 & 2.9 & 4.9 & 0.6 \\
$12+$ & 0.233 & 0.416 & 1.9 & 3.7 & 0.4 \\
$13+$ & 0.265 & 0.385 & 1.0 & 2.1 & 1.2 \\
$14+$ & 0.303 & 0.589 & 0.5 & 0.6 & 0.2 \\
$15+$ & 0.348 & 0.761 & 0.2 & $\mathbf{1 1 2 . 1}$ & 0.1 \\
\hline
\end{tabular}

